(c) American Dairy Science Association, 2003.

\title{
Ovarian Follicular Responses to High Doses of Pulsatile Luteinizing Hormone in Lactating Dairy Cattle
}

\author{
J. H. Hampton, B. E. Salfen, J. F. Bader, D. H. Keisler, and H. A. Garverick \\ *Animal Sciences Department, \\ University of Missouri, Columbia, 65211
}

\begin{abstract}
Two experiments in lactating dairy cows examined ovarian follicular responses to high, frequent doses of exogenous LH pulses at levels associated with follicular cysts. In Experiment 1, estrus was synchronized in 12 cyclic lactating cows $>40 \mathrm{~d}$ postpartum. Emergence of the second follicular wave (d 0) was determined by ultrasonography. Starting on d 1, cows received LH (40 $\mu \mathrm{g} / \mathrm{h} ; \mathrm{n}=7)$ or saline $(2 \mathrm{~mL} / \mathrm{h} ; \mathrm{n}=5)$ in hourly pulses for up to $5(n=5)$ or $7(n=7) d$. On d 2, all cows received two injections of $\mathrm{PGF}_{2} \alpha, 12 \mathrm{~h}$ apart. In experiment 2, 14 lactating cows (7 to $12 \mathrm{~d}$ postpartum) received $\mathrm{LH}$ $(40 \mu \mathrm{g} / \mathrm{h} ; \mathrm{n}=7)$ or saline $(1 \mathrm{~mL} / \mathrm{h} ; \mathrm{n}=7)$ in hourly pulses for $7 \mathrm{~d}$, beginning $24 \mathrm{~h}$ after start of the first follicular wave. Daily samples were used to determine serum concentrations of progesterone $\left(\mathrm{P}_{4}\right)$, estradiol- $17 \beta\left(\mathrm{E}_{2}\right)$, $\mathrm{LH}$, and FSH. Profiles of LH were determined from blood samples collected at 12-min intervals for $8 \mathrm{~h}$ on d 3. During infusion of LH, serum $\mathrm{P}_{4}$ and FSH were similar across treatments in both experiments. Serum $\mathrm{E}_{2}$ concentrations were similar in experiment 1 , but serum $\mathrm{E}_{2}$ was greater on $\mathrm{d} 2,3$, and 5 in LH-treated cows in experiment 2 . Infusion increased LH pulse frequency and amplitude in both experiments. Formation of cysts did not differ between LH- and saline-treated cows in either experiment ( 1 of 7 vs. 0 of 5 and 1 of 6 vs. 0 of 7 , respectively). Cows that ovulated had similar intervals to ovulation in experiment $1[6.0 \pm 0.1 \mathrm{~d}(\mathrm{LH}) \mathrm{vs}$. $6.4 \pm 0.2 \mathrm{~d}$ (saline)], but in experiment 2 , ovulation was $14 \mathrm{~d}$ earlier in LH-treated cows $(5.6 \pm 1.8 \mathrm{~d}$ vs $19.9 \pm$ $1.5 \mathrm{~d})$. In conclusion, high concentrations of $\mathrm{LH}$ are not solely responsible for formation of cysts in lactating dairy cows. Pulsatile infusion of LH stimulated follicular growth and steroidogenesis and decreased time to first ovulation in anestrous postpartum cows.
\end{abstract}

(Key words: ovarian cyst, luteinizing hormone, ovulation)

Received May 15, 2002.

Accepted October 2, 2002.

Corresponding author:H. A. Garverick; e-mail: garverickh@ missouri.edu.

\begin{abstract}
Abbreviation key: cysts = ovarian follicular cysts, $\mathbf{E}_{\mathbf{2}}$ $=$ estradiol-17 $\beta, \mathbf{P}_{\mathbf{4}}=$ progesterone, $\mathbf{R I A}=$ radioimmunoassay.
\end{abstract}

\section{INTRODUCTION}

Ten to $13 \%$ of dairy cattle in the United States develop ovarian follicular cysts (cysts) annually, resulting in infertility and economic loss for dairy producers. In dairy cows, follicular cysts have been defined as anovulatory, ovarian follicular structures $>25 \mathrm{~mm}$ in size that persist for at least $10 \mathrm{~d}$ in the absence of a corpus luteum. While some cysts persist for extended lengths of time, most regress over time and are replaced during subsequent follicular waves with new cysts (Garverick, 1997). Thus, undiagnosed or untreated cysts can extend calving intervals in afflicted animals. While therapies have been developed to treat cysts, the etiology of cysts remains poorly understood.

Previous work in our laboratory has demonstrated that elevated serum concentrations of LH are associated with the development and maintenance of cysts (Cook et al., 1991; Hamilton et al., 1995). In these studies, LH profiles of cows during development and maintenance of cysts were characterized by both high frequency and amplitude pulses without a preovulatorylike LH surge. The increase in basal LH concentrations was maintained until cysts spontaneously regressed or were successfully treated. Thus, high peripheral concentrations of LH may be associated with the development and (or) maintenance of cysts. In a preliminary study using cyclic, nonlactating dairy cows, infusion of LH in a high frequency, high amplitude manner for 5 d increased follicular size and delayed ovulation $(\geq 10$ $\mathrm{d}$ versus saline-treated controls) in two of three cows (H. A. Garverick, B. E. Salfen, and R. S. Youngquist, unpublished data). The objective of the current study was to determine whether chronic pulsatile infusion of LH into lactating dairy cows, in a manner that produced high frequency, high amplitude pulses of $\mathrm{LH}$, similar to those observed in cows with cysts, would result in the development of cysts. Alternatively, infusion of exogenous LH may stimulate ovarian follicular development and ovulation. 


\section{MATERIALS AND METHODS}

\section{Experiment 1: Cows with Normal Estrous Cycles}

Estrous cycles of 12 lactating dairy cows that were $>40 \mathrm{~d}$ postpartum were synchronized using a standard Ov-Synch protocol (Pursley et al., 1998). Briefly, cows received an i.m. injection of $100 \mu \mathrm{g}$ of GnRH (Cystorelin, Rhone Merieux, Athens, GA) on d 19, an i.m. injection of $25 \mathrm{mg}$ of $\mathrm{PGF}_{2} \alpha$ (Lutalyse, The Upjohn Company, Kalamazoo, MI) on d 12, and an i.m. injection of 100 $\mu \mathrm{g}$ GnRH on d 10. Ovarian structures were monitored daily by ultrasonography to determine time of ovulation and subsequent emergence of the second follicular wave (d 0). Emergence of the second follicular wave was characterized by recruitment of a new cohort of follicles to grow from $\leq 4$ to $>5 \mathrm{~mm}$ in diameter. One day after the emergence of the second follicular wave (D 1), cows were fitted with indwelling jugular catheters and were randomly assigned to begin receiving hourly pulsatile infusions (each pulse infusion lasting $<60 \mathrm{~s}$ ) of $\mathrm{LH}$ (USDA-bLH-B-6; $2.1 \mathrm{~S} 1 \mathrm{Units} / \mathrm{mg} ;<1 \%$ FSH activity; $40 \mu \mathrm{g} /$ pulse; $\mathrm{n}=7$ ) or saline ( $2 \mathrm{ml} /$ pulse; $\mathrm{n}=5$ ), administered via a computer-controlled syringe pump. In preliminary experiments, this level of $\mathrm{LH}$ infusion increased circulating $\mathrm{LH}$ in a pulsatile manner that was twice that observed in saline-treated cows and similar to cows developing and maintaining cysts (H. A. Garverick, B. E. Salfen, and R. S. Youngquist, unpublished data). On d 2, all cows received two i.m. injections of $\mathrm{PGF}_{2 \alpha}(25 \mathrm{mg}$ /injection) given $12 \mathrm{~h}$ apart. Pulsatile infusions of LH or saline were delivered until an ovulation was detected, or until a predetermined termination point ( $\mathrm{d} 5, \mathrm{n}=5$; or $\mathrm{d} 7, \mathrm{n}=7$ ), whichever occurred first. This protocol was similar to a preliminary experiment, in which infusion of $\mathrm{LH}$ for $5 \mathrm{~d}$ resulted in increased follicle size and delayed ovulation in two of three LHtreated, nonlactating cows (H. A. Garverick, B. E. Salfen, and R. S. Youngquist, unpublished data).

\section{Experiment 2: Early Postpartum Cows}

Fourteen early postpartum dairy cows were used in experiment 2. Following parturition, cows were monitored daily by ultrasonography to detect the initiation of the first postpartum follicular wave $(\mathrm{d} 0$; mean $=8$ $\mathrm{d}$ postpartum; range $=7$ to $12 \mathrm{~d}$ postpartum). Initiation of the first postpartum follicular wave was defined as emergence of the first developing cohort of follicles, following parturition, to grow $\geq 5 \mathrm{~mm}$ in diameter. Cows were fitted with indwelling jugular catheters and randomly assigned to receive LH (40 $\mathrm{g}$ /pulse; $\mathrm{n}=7)$ or saline $(1 \mathrm{ml} /$ pulse; $\mathrm{n}=7)$ as described in experiment 1 , for $7 \mathrm{~d}$, or until ovulation was detected.

\section{Blood Collection and Hormone Analysis}

In both experiments, blood samples were collected daily via jugular venipuncture from initiation of study until ovulation (experiment 1) or corpus luteum formation (experiment 2) to assess peripheral concentrations of LH, FSH, progesterone $\left(\mathbf{P}_{\mathbf{4}}\right)$, and estradiol-17 $\beta\left(\mathbf{E}_{\mathbf{2}}\right)$. Blood samples were also collected at 12-min intervals for $8 \mathrm{~h}$, beginning $48 \mathrm{~h}$ after initiation of infusions to verify delivery of $\mathrm{LH}$ and to characterize circulating concentrations of LH. Blood samples were allowed to clot overnight at $4^{\circ} \mathrm{C}$ and centrifuged $24 \mathrm{~h}$ later at 1800 $\times g$ for 30 min at $4^{\circ} \mathrm{C}$. Serum was harvested and stored at $-20^{\circ} \mathrm{C}$ until concentrations of $\mathrm{P}_{4}, \mathrm{E}_{2}, \mathrm{LH}$, and $\mathrm{FSH}$ were determined via radioimmunoassay (RIA).

Serum concentrations of $\mathrm{P}_{4}$ were determined using a direct, solid-phase RIA (Coat-A-Count; Diagnostic Products Corp., Los Angeles, CA; Kirby et al., 1997), and daily samples were measured in duplicate 100- $\mu$ l aliquots of serum in a single assay, with an intraassay CV of $1.8 \%$.

Aliquots of serum used to measure $\mathrm{E}_{2}$ were first subjected to reverse-phase chromatography extraction procedures. Briefly, octadecyl columns (SPEEDISK 96 Silica columns; $20 \mathrm{mg}$ sorbent mass; J. T. Baker, Phillipsburg, NJ) were prewashed with two column volumes of acetone, two volumes of HPLC-grade methanol, and two volumes of distilled water. Steroid-free serum (0.6 $\mathrm{ml}$ ) was aspirated through columns and was followed by one column volume of 1:4 acetone:water solution. Columns were dried using positive pressure for $3 \mathrm{~min}$, then rinsed with two column volumes of both methanol and distilled water. Following this preparation of each column, $0.6 \mathrm{ml}$ of serum, in duplicate, was aspirated through columns, followed by one column volume of $1: 4$ acetone:water solution. Columns were dried for $3 \mathrm{~min}$ under positive pressure, and the $\mathrm{E}_{2}$-containing fraction was collected by two successive column aspirations with $0.3 \mathrm{ml}$ of methanol. Methanol fractions were evaporated under gentle air stream and by warming to $37^{\circ} \mathrm{C}$. Recovery of $\left[{ }^{125} \mathrm{I}\right]$ estradiol- $17 \beta$ from chromatography columns were $>90 \%$. Fractions were then resolubilized in $0.1 \mathrm{ml}$ of $1 \% \mathrm{BSA}$ in buffer $\left(0.01 \mathrm{M} \mathrm{PO}_{4}, 0.15 \mathrm{M} \mathrm{NaCl}\right.$, and $0.01 \%$ sodium azide; $\mathrm{pH}=7.2$ ), and concentrations of $\mathrm{E}_{2}$ were determined using a previously validated assay (Rozell and Keisler, 1990). Separation of bound and free $\mathrm{E}_{2}$ was performed using a pre-precipitated, sheep antirabbit second antibody, followed by centrifugation at $1800 \times \mathrm{g}$ for $30 \mathrm{~min}$. Radioactivity was counted in pellets in a gamma counter for $2 \mathrm{~min}$ per tube. The limit of detection was $0.25 \mathrm{pg}$ (90\% binding) and intraand interassay coefficients of variation were 7.3 and $10 \%$, respectively. 
Serum concentrations of $\mathrm{LH}$ were determined as previously described by Zaied et al. (1980) using anti-oLH TEA \# 35 (J. J. Reeves, Washington State Univ., Pullman, WA). Concentrations of LH were measured in duplicate $200-\mu \mathrm{l}$ aliquots of serum. Intra- and interassay CV for three serum pools were 5.2 and $10.8 \%$, respectively, across seven assays.

Serum concentrations of FSH were determined as previously described (Garverick et al., 1988). Concentrations of FSH were measured in duplicate 200- $\mu$ l aliquots of serum. NIAMDD oFSH RP-1 was used in reference preparations. Intra- and inter-assay $\mathrm{CV}$ for three serum pools were 3.2 and $5.5 \%$, respectively, across two assays.

\section{Statistical Analyses}

Differences in the proportion of cows forming cysts were determined by Fisher's exact test (Ott, 1993) using the frequency procedures of SAS (version 8.0; SAS Inst., Inc., Cary, NC). In cows that ovulated, mean time to ovulation from initiation of treatment was determined by analysis of variance (Ott, 1993) using the general linear models procedures of SAS. Differences between treatment means were determined using pairwise $t$ test comparisons (Ott, 1993). In Experiment 1, time to ovulation was not different between cows infused for 5 or $7 \mathrm{~d}(P=0.18)$; therefore, data were pooled.

Mean serum LH concentrations, pulse frequencies (number of LH pulses/8-h period), pulse amplitudes, and inter-pulse intervals were determined using CLUSTER analysis procedures (Veldhuis and Johnson, 1986) with a minimum LH pulse equaling $1 \mathrm{ng} / \mathrm{ml}$. Effects of treatment on mean LH concentration, pulse frequency, pulse amplitude, and interpulse interval were determined by analysis of variance using the general linear models procedures of SAS. Differences among treatment means were determined using pairwise $t$-test comparisons (Ott, 1993).

For analysis of daily serum samples, one cow in experiment 1 (LH treatment) and one cow in experiment 2 (LH treatment) were excluded from further analysis due to failure to ovulate. Additionally, one cow from experiment 2 (LH treatment) was excluded from further analysis due to lack of ovarian function. Effects of treatment on daily follicular diameter, $\mathrm{P}_{4}, \mathrm{E}_{2}, \mathrm{LH}$, and FSH concentrations were determined by analysis of variance using the mixed models procedures of SAS (Littell et al., 1998). Cow within treatment was used as the error term with time serving as the repeated measure. Differences between group means were determined when treatment $\times$ time interactions were significant using pairwise $t$-tests comparisons (Ott, 1993).

\section{RESULTS}

\section{Experiment 1: Cows with Normal Estrous Cycles}

Pulsatile infusion of $\mathrm{LH}$, at the rate of $40 \mu \mathrm{g} / \mathrm{h}$, resulted in an increase in mean LH concentrations $(P<$ $0.001), \mathrm{LH}$ pulse frequency and amplitude $(P \leq 0.01)$, as determined during the frequent blood collection period, in LH- vs. saline-treated cows (Table 1, Figure 1).

Number of cows forming cysts did not differ between LH- and saline-treated cows ( 1 of 7 vs. 0 of 5, respectively; $P=0.58$ ). While one cow in the LH-treatment group formed a cyst following treatment, six of seven cows in the LH treatment group and five of five cows in the saline-treatment group ovulated before the end of treatment.

In cows that ovulated, mean time from detection of the second follicular wave to ovulation did not differ between treatment groups ( $P=0.10)$, and occurred by $6.0 \pm 0.1 \mathrm{~d}$ in LH-treated cows and $6.4 \pm 0.2 \mathrm{~d}$ in salinetreated cows. Corpus luteum formation was observed in all cows following ovulation as evidenced via ultrasonography (data not shown).

Mean daily follicular diameter and concentrations of $\mathrm{LH}$ and $\mathrm{P}_{4}$ in cows that ovulated are depicted in Figure 2. Follicle diameter increased in LH- and saline-treated cows during the experimental period until ovulation and did not differ between treatment groups $(P=0.49)$. Mean daily concentrations of $\mathrm{LH}$ were numerically greater in LH- vs. saline-treated cows during the infusion period (Figure 2), but treatment, time, and treatment $\times$ time interactions were not significant $(P \geq 0.23)$ in the daily samples. While initially greater in salinetreated cows $(P \leq 0.05)$, serum concentrations of progesterone in both groups of cows declined to and remained less than $1 \mathrm{ng} / \mathrm{ml}$ following prostaglandin treatment. Mean daily concentrations of FSH and $\mathrm{E}_{2}$ are not shown, as treatment $\times$ time interactions were not significant ( $P=0.89$ and $P=0.55$, respectively).

\section{Experiment 2: Early Postpartum Cows}

As in experiment 1, pulsatile infusion of $\mathrm{LH}$ at the rate of $40 \mu \mathrm{g} / \mathrm{h}$ resulted in greater mean serum concentrations of LH in LH- vs. saline-treated cows (Figure $1 ; P<0.0001)$. As shown in Table 1, greater basal concentrations of LH in LH- vs. saline-treated cows were the result of greater LH pulse frequencies and pulse amplitudes $(P \leq 0.001)$ in LH-treated cows.

As in experiment 1 , the number of cows forming cysts did not differ between LH- and saline-treated cows (one of six versus zero of seven, respectively; $P=0.46$ ). However, LH treatment reduced the time to first ovulation postpartum $(P=0.0001)$. In cows that ovulated, mean time to ovulation following initiation of infusion was 
Table 1. Differences in serum LH concentrations in cows receiving continuous peripheral infusions of saline or LH during an 8-h serial blood collection on experimental d 3.

\begin{tabular}{|c|c|c|c|c|}
\hline \multirow[b]{3}{*}{ Variable } & \multicolumn{4}{|c|}{ Physiological Status } \\
\hline & \multicolumn{2}{|c|}{$\begin{array}{c}\text { Experiment 1: Cows with Normal } \\
\text { Estrous Cycles }\end{array}$} & \multicolumn{2}{|c|}{$\begin{array}{l}\text { Experiment 2: Early } \\
\text { Postpartum Cows }\end{array}$} \\
\hline & $\mathrm{LH}(\mathrm{n}=7)$ & Saline $(\mathrm{n}=5)$ & $\mathrm{LH}(\mathrm{n}=7)$ & Saline $(\mathrm{n}=7)$ \\
\hline Mean LH (ng/mL) & $2.32 \pm 0.18^{\mathrm{a}}$ & $0.78 \pm 0.21^{\mathrm{b}}$ & $2.68 \pm 0.16^{\mathrm{c}}$ & $1.05 \pm 0.16^{\mathrm{d}}$ \\
\hline LH pulse frequency (\# pulses $/ 8 \mathrm{~h}$ ) & $6.42 \pm 0.53^{\mathrm{a}}$ & $4.00 \pm 0.62^{\mathrm{b}}$ & $6.14 \pm 0.44^{\mathrm{c}}$ & $2.57 \pm 0.44^{\mathrm{d}}$ \\
\hline $\mathrm{LH}$ pulse amplitude $(\mathrm{ng} / \mathrm{mL})$ & $3.52 \pm 0.33^{\mathrm{a}}$ & $1.50 \pm 0.39^{b}$ & $3.78 \pm 0.30^{\mathrm{c}}$ & $1.87 \pm 0.32^{\mathrm{d}}$ \\
\hline Inter-pulse interval (min) & $57.7 \pm 18.0^{\mathrm{a}}$ & $101.2 \pm 21.3^{\mathrm{a}}$ & $60.0 \pm 15.4^{\mathrm{c}}$ & $123.0 \pm 16.6^{\mathrm{d}}$ \\
\hline Mean nadir $(\mathrm{ng} / \mathrm{mL})$ & $1.53 \pm 0.16^{\mathrm{a}}$ & $0.42 \pm 0.18^{\mathrm{b}}$ & $1.89 \pm 0.13^{\mathrm{c}}$ & $0.77 \pm 0.14^{\mathrm{d}}$ \\
\hline
\end{tabular}

${ }^{\mathrm{a}, \mathrm{b}}$ Within row and physiological status, values with different superscripts differ $P \leq 0.01$.

${ }^{\mathrm{c}, \mathrm{d} W i t h i n}$ row and physiological status, values with different superscripts differ $P \leq 0.01$.

$5.6 \pm 1.8 \mathrm{~d}$ in LH-treated cows, whereas mean time to ovulation from initiation of infusion was $19.9 \pm 1.5 \mathrm{~d}$ in saline-treated control cows. Treatment, time, and treatment $\times$ time interactions were not significant for daily concentrations of FSH $(P \geq 0.27)$.

Mean daily follicle diameter and serum concentrations of $\mathrm{LH}, \mathrm{E}_{2}$, and $\mathrm{P}_{4}$ are depicted in Figure 3. Mean daily follicle diameter was greater in cows treated with

\section{Experiment 1: Cows with Normal Estrous Cycles}
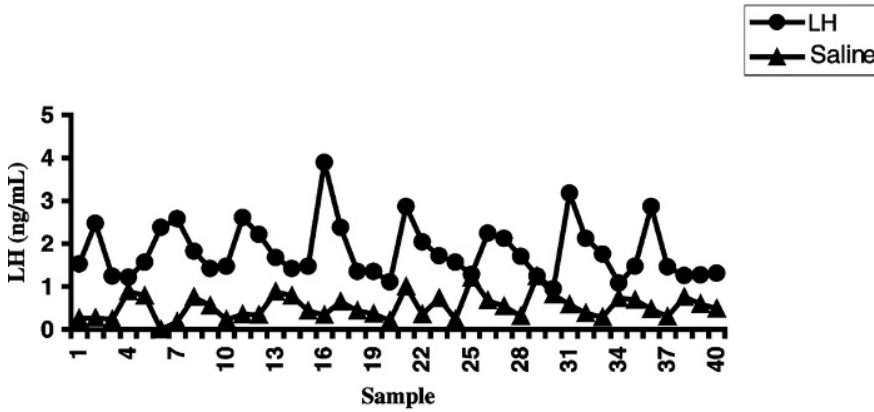

Experiment 2: Earły Postpartum Cows

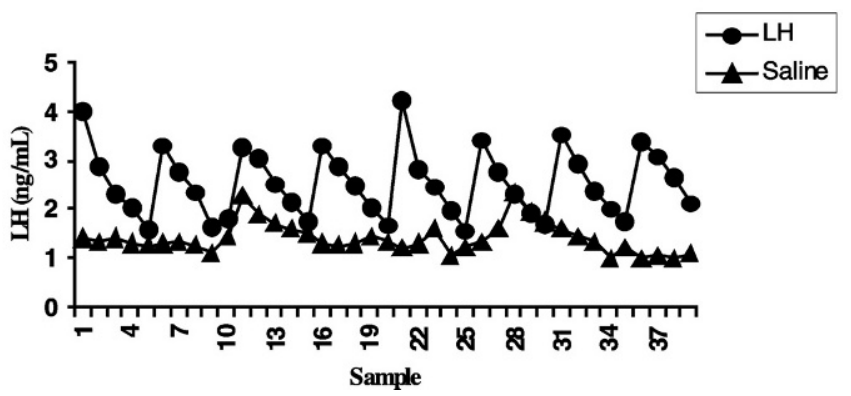

Figure 1. Representative LH profiles during an 8-h period from cows treated with LH (solid circles) or saline (solid triangle) in experiment 1 (top) and experiment 2 (bottom).
LH vs. saline during the infusion period until ovulation $(P=0.05)$. In saline-treated cows, the first dominant follicle, postpartum, reached a smaller maximum diameter $(13.0 \pm 0.9 \mathrm{~mm} ; P=0.0006)$ than in LH-treated cows $(19.6 \pm 1.6 \mathrm{~mm})$ and failed to ovulate. Instead, the first ovulatory follicle in saline-treated cows arose from subsequent waves of follicular growth.

During the infusion period, LH treatment resulted in an increase in mean daily concentrations of $\mathrm{LH}$ ( $P$ $\leq 0.03$ ) in LH- vs. saline-treated cows. Greater mean concentrations of $\mathrm{LH}$ were coincident with greater concentrations of $\mathrm{E}_{2}$ on $\mathrm{d} 2,3$, and $5(P \leq 0.03)$ during the infusion period in LH-treated cows. Daily concentrations of $\mathrm{P}_{4}$ were minimal during the infusion period in both LH- and saline-treated cows $(P \geq 0.85)$. However, following ovulation, concentrations of $\mathrm{P}_{4}$ increased to levels greater than $1 \mathrm{ng} / \mathrm{mL}$ by d 10 following initiation of LH treatment, but failed to increase in saline-treated cows $(P=0.93)$ during this period.

\section{DISCUSSION}

In both experiments 1 and 2, pulsatile infusion of $\mathrm{LH}$ increased peripheral concentrations of $\mathrm{LH}$ and resulted in patterns of LH in the serum that were characterized by high frequency and high-amplitude pulses. The pulsatile pattern and mean concentration of $\mathrm{LH}$ achieved during both experiments were approximately twice that observed in cows with normal estrous cycles and were similar to concentrations observed in cows during development and maintenance of cysts (Cook et al., 1990; Hamilton et al., 1995; Calder et al., 1999). The LH profiles in saline-treated cows in experiment 1 were characterized by high-frequency, low-amplitude pulses, whereas LH profiles in saline-treated cows in experiment 2 were characterized by low-frequency, low-amplitude pulses. Whereas differences in daily mean serum concentrations of $\mathrm{LH}$ were detectable during the early postpartum period in LH- vs. saline-treated cows (ex- 

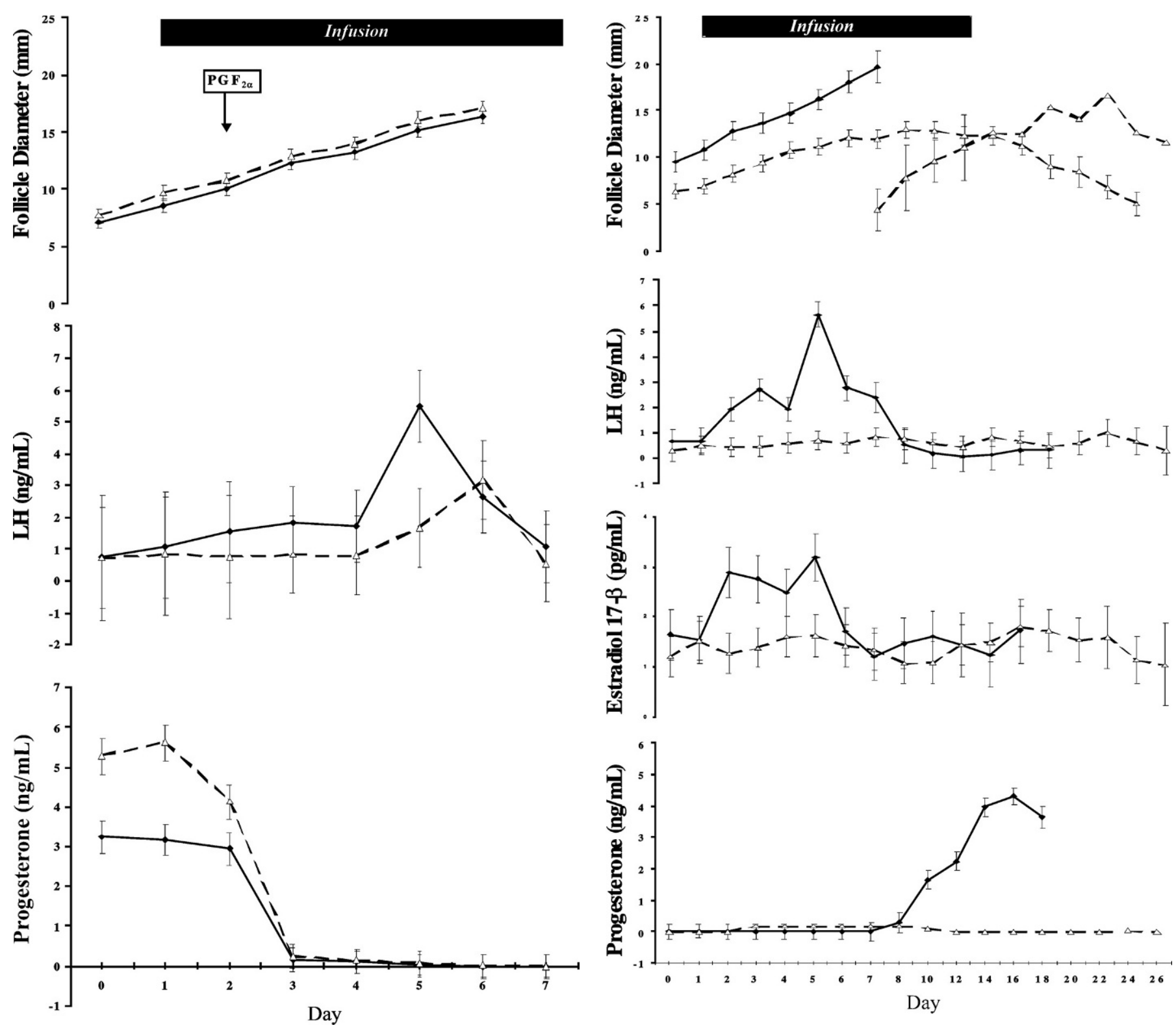

Figure 2. Least squares means $\pm \mathrm{SEM}$ of follicular diameter $(\mathrm{mm})$, $\mathrm{LH}$ concentrations $(\mathrm{ng} / \mathrm{ml})$, and progesterone concentrations $(\mathrm{ng} / \mathrm{ml})$ in LH- (solid line) and saline-treated (broken line) cyclic cows (experiment 1) during the experimental period.

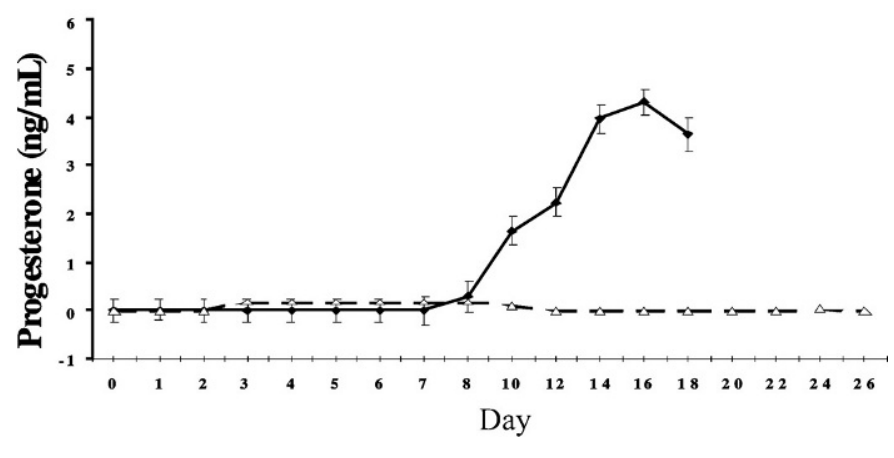

Figure 3. Least squares means \pm SEM of follicular diameter ( $\mathrm{mm})$, $\mathrm{LH}(\mathrm{ng} / \mathrm{ml})$, estradiol- $17 \beta(\mathrm{pg} / \mathrm{ml})$, and progesterone concentrations ( $\mathrm{ng} / \mathrm{ml}$ ) in LH (solid line) and saline-treated (broken line) early postpartum cows (experiment 2) during the experimental period.

periment 2), no differences existed in daily mean serum concentrations of $\mathrm{LH}$ between $\mathrm{LH}$ - and saline-treated cows (experiment 1). However, based on analysis of concentrations of $\mathrm{LH}$ in samples collected during the frequent blood collection period, cows treated with LH had peripheral concentrations of LH more than double that of saline-treated cows, regardless of physiological status (Table 1). Yet, in the current study, experimental alteration of peripheral levels of LH did not result in the formation of cysts in either experiment. Combining

both physiological states, 11 of 13 cows treated with LH ovulated by $\mathrm{d} 7$ of treatment. Ovulation was associated with a preovulatory increase in peripheral $\mathrm{LH}$, disappearance of the largest follicular structure, and formation of luteal tissue.

During the early postpartum period (experiment 2), pulsatile infusions of $\mathrm{LH}$ resulted in ovulation by $\mathrm{d} 7$ (about $14 \mathrm{~d}$ postpartum) in five of six cows, vs. zero of seven cows treated with saline. Infusion of LH resulted in ovulation of the first-wave postpartum dominant fol- 
licle. In saline-treated cows, none of the first-wave dominant follicles ovulated. Maximum size attained by the first-wave dominant follicle in saline-infused cows was smaller, and mean concentrations of $\mathrm{E}_{2}$ were lower, than in LH-treated cows. Postpartum cows infused with saline ovulated the second or third wave-dominant follicle. Previous studies have shown that while the first dominant follicle can appear as early as 1 wk postpartum, first ovulation does not typically occur until about $20 \mathrm{~d}$ postpartum in dairy cows (Savio et al., 1990) and $35 \mathrm{~d}$ postpartum in beef cows (Murphy et al., 1990). The ability to ovulate coincides with increases in $\mathrm{LH}$ pulse frequency from two to three pulses per 6-h period to five to seven pulses per $6 \mathrm{~h}$ (Savio et al., 1990; Stagg et al., 1998). This suggests that low LH pulse frequency is associated with postpartum anestrus. Duffy et al. (2000) have shown that increasing LH pulse frequency alone can decrease interval to first ovulation and (or) increase maximum size of dominant follicles in early postpartum beef cows. These results are consistent with data from the current study in which increases in $\mathrm{LH}$ pulse frequency and amplitude were associated with decreased interval to ovulation and increased maximum diameter of the first postpartum dominant follicle.

Our original hypothesis was that the early postpartum period would be more conducive to cyst formation, because development of cysts is greatest during this period of time (Kesler and Garverick, 1982). Concentrations of $\mathrm{P}_{4}$ are typically low early postpartum because corpora lutea are absent before the first postpartum ovulation. A study by Caraty and Skinner (1999) implicated progesterone in the establishment of an LH surge in sheep. However, cows in the current study were capable of producing an LH-surge despite concentrations of $\mathrm{P}_{4}$ remaining below the detection limit of the assay before and during the infusion period. During the postpartum period, infusions of LH were associated with increased follicular growth and steroidogenic output of the first postpartum dominant follicle, because LHtreated cows had greater follicular diameters and serum concentrations of $\mathrm{E}_{2}$ than saline-treated controls. This is consistent with recent work by Duffy et al. (2000), who reported increased peripheral concentrations of $\mathrm{E}_{2}$ following LH treatments to postpartum beef cows. Increases in $\mathrm{E}_{2}$ have been established as potent stimulators of the preovulatory LH-surge (Karsch et al., 1997; Gazal et al., 1998). Therefore, in the current study, treatments of LH increased the estrogenic output of the first postpartum dominant follicle resulting in an LH surge, followed by ovulation and formation of a corpus luteum.

Previous work in our laboratory has shown that both naturally occurring and steroid-induced cysts were associated with the absence of a preovulatory LH surge and functional corpus luteum (Cook et al., 1990, 1991; Hamilton et al, 1995). Findings from other laboratories have also implicated alterations in the LH surge in the etiology of cysts (Yoshioka et al., 1996; Dobson et al., 1997; Christman et al., 2000). A recent study indicated that a large follicle anovulatory condition, similar to cysts, can be induced following an estradiol-induced GnRH surge without subsequent $\mathrm{P}_{4}$ exposure (Gümen et al., 2002). Accordingly, one of the established treatments for inducing cyst regression in dairy cattle is administration of $\mathrm{GnRH}$ or a GnRH-like product that, in turn, results in an LH surge (Garverick, 1997). Therefore, while the model used in the current studies was successful in simulating one of the factors associated with cyst development (increased basal concentrations of $\mathrm{LH}$ ), it failed to simulate other factors associated with the etiology of cysts (absence of an LH surge).

While these data provide evidence that increased basal secretion of $\mathrm{LH}$ is not the sole factor responsible for the development of cysts, they do not preclude the involvement of LH in the maintenance of cysts. Previous work from our laboratory has shown that administration of $\mathrm{P}_{4}$ to cows with cysts results in a decrease in both LH pulse frequency and pulse amplitude within $24 \mathrm{~h}$ of administration (Calder et al., 1999). Reduction in $\mathrm{LH}$ concentrations and increased concentrations of $\mathrm{P}_{4}$ resulted in atresia of cysts and development of normal ovulatory follicles. In addition, some cows that develop cysts resume ovulatory ovarian cycles without exogenous hormonal therapy. In cows with cysts that resume ovulatory ovarian cycles, serum concentrations of LH were lower than in cows that maintained or developed new cysts (Hamilton et al., 1995). Therefore, while high concentrations of $\mathrm{LH}$ are not the sole factor responsible for the formation of cysts, high concentrations of $\mathrm{LH}$ may be required for the maintenance of cysts.

\section{CONCLUSIONS}

Pulsatile infusions of LH stimulated an increase in steroidogenic output from the first postpartum dominant follicle of dairy cows. However, increases in peripheral concentrations of $\mathrm{LH}$ were not associated with ovarian cyst development in either cycling or early postpartum cows, because most cows ovulated by the end of treatment. Pulsatile infusion of LH into early postpartum cows stimulated follicular growth and steroidogenesis that was followed by ovulation of the first-wave dominant follicle. While these data provide evidence that increased basal secretion of $\mathrm{LH}$ is not the sole factor responsible for the development of cysts, they do not preclude the involvement of $\mathrm{LH}$ in the maintenance of cysts. 


\section{REFERENCES}

Calder, M. D., B. E. Salfen, B. Bao, R. S. Youngquist, and H. A. Garverick. 1999. Administration of progesterone to cows with ovarian follicular cysts results in a reduction in mean LH and LH pulse frequency and initiates ovulatory follicular growth. J. Anim. Sci. 77:3037-3042.

Caraty, A., and D. C. Skinner. 1999. Progesterone priming is essential for the full expression of the positive feedback effect of estradiol in inducing the preovulatory gonadotropin-releasing hormone surge in the ewe. Endocrinology 140:165-170.

Christman, S. A., M. T. Bailey, W. A. Head, and J. E. Wheaton. 2000. Induction of ovarian cystic follicles in sheep. Domest. Anim. Endocrinol. 19:133-146.

Cook, D. L., C. A. Smith, J. R. Parfet, R. S. Youngquist, E. M. Brown, and H. A. Garverick. 1990. Fate and turnover rate of ovarian follicular cysts in dairy cattle. J. Reprod. Fertil. 90:37-46.

Cook, D. L., J. R. Parfet, C. A. Smith, G. E. Moss, R. S. Youngquist, and H. A. Garverick. 1991. Secretory patterns of LH and FSH during development and hypothalamic and hypophysial characteristics following development of steroid-induced ovarian follicular cysts in dairy cattle. J. Reprod. Fertil. 91:19-28.

Dobson, H., B. K. Campbell, B. M. Gordon, and R. J. Scaramuzzi. 1997. Endocrine activity of induced persistent follicles in sheep. Biol. Reprod. 56:208-213.

Duffy, P., M. A. Crowe, M. P. Boland, and J. F. Roche. 2000. Effect of exogenous LH pulses on the fate of the first dominant follicle in postpartum beef cows nursing calves. J. Reprod. Fertil. 118:9-17.

Garverick, H. A., J. R. Parfet, C. N. Lee, J. P. Copelin, R. S. Youngquist, and M. F. Smith. 1988. Relationship of pre- and post-ovulatory gonadotropin concentrations to subnormal luteal function in postpartum beef cattle. J. Anim. Sci. 66:104-111.

Garverick, H. A. 1997. Ovarian follicular cysts in dairy cows. J. Dairy Sci. 80:995-1004

Gazal, O. S., L. S. Leshin, R. L. Stanko, M. G. Thomas, D. H. Keisler, L. L. Anderson, and G. L. Williams. 1998. Gonadotropin-releasing hormone secretion into third-ventricle cerebrospinal fluid of cattle:correspondence with the tonic and surge release of luteinizing hormone and its tonic inhibition by suckling and neuropeptide Y. Biol. Reprod. 59:676-683.

Gümen, A., R. Sartori, F. M. J. Costa, and M. C. Wiltbank. 2002. A GnRH/LH surge without subsequent progesterone exposure can induce development of follicular cysts. J. Dairy Sci. 85:43-50.

Hamilton, S. A., H. A. Garverick, D. H. Keisler, Z. Z. Xu, K. Loos, R. S. Youngquist, and B. E. Salfen. 1995. Characterization of ovarian follicular cysts and associated endocrine profiles in dairy cows. Biol. Reprod. 53:890-898.

Karsch, F. J., J. M. Bowen, A. Caraty, N. P. Evans, and S. M. Moenter. 1997. Gonadotropin-releasing hormone requirements for ovulation. Biol. Reprod. 56:303-309.

Kesler, D. J., and H. A. Garverick. 1982. Ovarian cysts in dairy cattle: a review. J. Anim. Sci. 55:1147-1159.

Kirby, C. J., M. F. Smith, D. H. Keisler, and M. C. Lucy. 1997. Follicular function in lactating dairy cows treated with sustainedrelease bovine somatotropin. J. Dairy Sci. 80:273-285.

Littell, R. C., P. R. Henry, and C. B. Ammerman. 1998. Statistica analysis of repeated measures data using SAS procedures. J. Anim. Sci. 76:1216-1231.

Murphy, M. G., M. P. Boland, and J. F. Roche. 1990. Pattern of follicular growth and resumption of ovarian activity in post-partum beef suckler cows. J. Reprod. Fertil. 90:523-533.

Ott, R. L. 1993. An Introduction to Statistical Methods and Data Analysis. 4th ed. Wadsworth Publishing Co., Belmont, CA.

Pursley, J. R., R. W. Silcox, and M. C. Wiltbank. 1998. Effect of time of artificial insemination on pregnancy rates, calving rates, pregnancy loss, and gender ratio after synchronization of ovulation in lactating dairy cows. J. Dairy Sci. 81:2139-2144.

Rozell, T. G., and D. H. Keisler. 1990. Effects of oestradiol on LH, FSH, and prolactin in ovariectomized ewes. J. Reprod. Fertil. 88:645-653.

Savio, J. D., M. P. Boland, N. Hynes, and J. F. Roche. 1990. Resumption of follicular activity in the early post-partum period of dairy cows. J. Reprod. Fertil. 88:569-579.

Stagg, K., L. J. Spicer, J. M. Sreenan, J. F. Roche, and M. G. Diskin. 1998. Effect of calf isolation on follicular wave dynamics, gonadotropin and metabolic hormone changes, and interval to first ovulation in beef cows fed either of two energy levels postpartum. Biol. Reprod. 59:777-783.

Veldhuis, J. D., and M. L. Johnson. 1986. Cluster analysis: a simple, versatile, and robust algorithm for endocrine pulse detection. Am. J. Physiol. 250:E486-E493.

Yoshioka, K., S. Iwamura, and H. Kamomae. 1996. Ultrasonic observations on the turnover of ovarian follicular cysts and associated changes of plasma LH, FSH, progesterone, and oestradiol-17 beta in cows. Res. Vet. Sci. 61:240-244.

Zaied, A. A., H. A. Garverick, C. J. Bierschwal, R. G. Elmore, R. S. Youngquist, and A. J. Sharp. 1980. Effect of ovarian activity and endogenous reproductive hormones on $\mathrm{GnRH}$-induced ovarian cycles in postpartum dairy cows. J. Anim. Sci. 50:508-513. 